\title{
BIOARCHAEOLOGICAL ANALYSIS OF THE MOUNTED ARCHERS FROM THE HUNGARIAN CONQUEST PERIOD (10TH CENTURY): HORSE RIDING AND ACTIVITY-RELATED SKELETAL CHANGES
}

\author{
William Berthon ${ }^{1,2,3}$ \\ ${ }^{1}$ Department of Biological Anthropology, University of Szeged, Hungary; \\ ${ }^{2}$ École Pratique des Hautes Études, Paris Sciences et Lettres (PSL) University, Paris, France; \\ ${ }^{3}$ UMR 5199 PACEA, CNRS/University of Bordeaux, Pessac, France \\ Supervisors: Dr. Olivier Dutour, Dr. György Pálfi \\ Co-supervisors: Dr. Hélène Coqueugniot, Dr. László Révész
}

\begin{abstract}
Archaeological and historical sources attest that tribes of semi-nomadic populations conquered the Carpathian Basin with powerful armies of mounted archers at the turn of the 9th and 10th centuries, which led to the foundation of the Kingdom of Hungary a hundred years later. Cemeteries from that period often provide cases of deposits of archery and horse riding equipment, as well as horse bones associated with the individuals in the graves. The close association between these items and the skeletons, together with the well-known historical context, allows postulating that the concerned individuals practiced horse riding during their life.

The doctoral research had two main objectives. The first one was to contribute to the research on activity reconstructions in past populations with the identification of skeletal changes that could more reliably be associated with the practice of horse riding, in particular. The second objective was to bring an ethnoarchaeological contribution by possibly improving our understanding of the societies from the Hungarian Conquest period and their funerary practices.

We selected a sample of 67 individuals from the 10th-century Hungarian cemetery of SárrétudvariHizóföld, which was divided into two groups of individuals, according to the presence or absence of riding deposit in their graves. We also selected a modern (19-20th century) comparison group of 47 presumed non-rider individuals from the documented collection of Lisbon. We analysed different types of skeletal changes commonly used as indicators of activity and behaviour in past populations. Various direct measurements of the lower limb bones were also used to calculate indices of shape and robusticity. Statistical analyses mostly revealed significant differences between the Hungarian groups and the comparison group from Lisbon. They concerned some skeletal changes that can be linked to the riding practice and seem to be promising indicators for this activity. Comparisons between groups also revealed that the Hungarian individuals without riding deposit in their grave were likely riders as well. Both objectives of this research have thus been achieved.

We took into consideration most of the pitfalls inherent to research on activity-related skeletal changes, leading to several limitations, such as relatively restricted sample sizes in the archaeological groups, which should be improved in the future. In addition, the multifactorial aetiology of the skeletal changes represented one of the main difficulties for their interpretation in terms of activity. In that regard, we performed an exploratory analysis of the microarchitecture of a muscle insertion site, of which promising results will need to be confirmed with further research with the aim of improving the reconstruction of activities in past populations.
\end{abstract}

Keywords: Paleopathology; Horse riding; Activity-related skeletal changes; Hungarian Conquest period. 


\section{Introduction and objectives}

In some cases, material archaeological remains, such as artefacts or built structures, are not indicative of the activities performed by individuals during their life, in past populations. The analysis of the individuals' skeletal remains represents then the most direct or sometimes the only way to address the question. Some pathological or nonpathological changes observed on human bones can indeed be related to activities practiced during life (Dutour 1986, 1992, Capasso et al. 1999, Jurmain et al. 2012, Schrader 2019). This results from bones' ability to adapt their shape and structure in response to mechanical loading related to physical activity. Scholars have considered the reconstruction of activities from skeletal changes in past populations as "Bioarchaeology's Holy Grail", representing, in fact, a sort of ultimate goal, which is hardly accessible due to many methodological pitfalls that must be acknowledged (Jurmain et al. 2012).

Among all activities, horse riding, in particular, has interested bioarchaeologists and paleopathologists for several decades as it brought profound and lasting changes in the history of human cultural evolution concerning major aspects such as trade, settlement, warfare, subsistence, social organization and political ideology (Anthony 2007). The use of horses for transportation also considerably contributed to the circulation of languages, Indo-European in particular, as well as cultures and diseases, among other things.

Although some bone changes observed on horse skeletal remains can be considered as evidence of riding, the existence of a direct link between specific changes and the practice of horse riding has not yet been unarguably demonstrated with regard to human skeletal remains. Yet various types of skeletal changes have been described as part of a "horse riding syndrome", i.e., as possible indicators for the regular or intense practice of horse riding (Miller and Reinhard 1991, Pálfi 1992, Molleson and Hodgson 1993, Blondiaux 1994, Courtaud and Rajev 1998, Erickson et al. 2000, Belcastro and Facchini 2001, Ustundag and Deveci 2011, Baillif-Ducros et al. 2012, Tichnell 2012, Anđelinovic et al. 2015, Khudaverdyan et al. 2016, Baillif-Ducros 2018, Djukic et al. 2018, Fuka 2018). The lack of specificity of the changes and their multifactorial etiology are, however, among the various confounding factors that characterize this field of research and that are not systematically acknowledged (Dutour 1992, Jurmain et al. 2012). This, together with the absence, in most of the studies, of contextual evidence connecting the individuals with an activity and the lack of comparison groups, often result in limited or unreliable interpretations of skeletal changes in terms of specific activities, such as riding. In the end, we cannot evaluate which skeletal changes mentioned in the literature can be considered as reliable indicators for the practice of horse riding.

Archaeological and historical sources attest that tribes of semi-nomadic populations conquered the Carpathian Basin with powerful armies of mounted archers at the turn of the 9th and 10th centuries, which led to the foundation of the Kingdom of Hungary a hundred years later. Cemeteries from that period often provide cases of deposits of archery and horse riding equipment as well as horse bones associated with the individuals in the graves (Révész 2003). The close association between these items and the skeletons, together with the well-known historical context, allows postulating that the concerned individuals practiced horse riding during their life. Those populations are, thus, among the most pertinent to be used to perform methodological investigations on activity-related skeletal changes and, on horse riding, in particular.

The doctoral research had two main objectives. The first one was to contribute to the research on activity reconstructions in past populations with the identification of skeletal 
changes that could more reliably be associated with the practice of horse riding, in particular. The second objective was to bring an ethnoarchaeological contribution by possibly improving our understanding of the funerary practices of the societies from the Hungarian Conquest period.

\section{Materials and methods}

We limited the effect of sex and age on the development of skeletal changes by including only adult males in our materials. This way, we selected a sample of 67 individuals from the 10th-century Hungarian cemetery of Sárrétudvari-Hízóföld, which was divided into two groups of individuals, according to the presence or absence of riding deposit in their grave (17 and 50 individuals, respectively; Pálfi 1992, 1997, Nepper 2002). We also selected a comparison sample of 47 individuals of known occupation from the documented collection of Lisbon (Cardoso 2006, Alves Cardoso and Henderson 2013). They mostly lived during the first half of the 20th century, in an important urban area, with electricity and modern means of transport. We can, therefore, confidently assume that they were a non-riding population.

Young and mature adult individuals were distinguished for certain analyses to limit the influence of ageing, and some pathological cases were also excluded according to the type of analyses.

We analysed different types of skeletal changes commonly used as indicators of activity and behaviour in past populations and investigated, in particular:

- changes observed at 13 entheses (muscles attachment sites) on the coxal bone, femur, patella, tibia and the calcaneus (Hawkey and Merbs 1995, Mariotti et al. 2004, Villotte 2006, Mariotti et al. 2007, Henderson et al. 2016);

- changes at the hip, knee (patellofemoral and tibiofemoral) and ankle joints (Buikstra and Ubelaker 1994, Rogers and Waldron 1995, Weiss and Jurmain 2007);

- six morphological variants of the femur, including the variations of the anterior aspect of the femoral head-neck junction (Finnegan 1978, Villotte and Knüsel 2009, Radi et al. 2013);

- the presence of vertical herniations of intervertebral disc tissue in the vertebrae (Schmorl's nodes; Knüsel et al. 1997, Ustundag 2009);

- the presence of spondylolysis, a defect in the posterior part of the vertebrae (Bridges 1989, Merbs 1989, Molnar 2006);

- $\quad$ acute traumatic fractures of the upper and lower skeleton (Pálfi 1992, Larsen 1997, Jurmain 1999, Buzon and Richman 2007).

In addition, various direct measurements of the main lower limb bones were also used to calculate indices of shape and robusticity, including an index of ovalisation of the acetabulum (Baillif-Ducros et al. 2012, Sarry et al. 2016). We selected these skeletal changes considering anatomical and functional aspects and taking into account the bioanthropological and sports medicine literature on horse riding.

\section{Results and discussion}

Statistical analyses mostly revealed significant differences between the Hungarian groups with or without riding deposit and the comparison group from Lisbon. These differences concerned especially various skeletal changes for which frequencies and values 
were higher in the Hungarian groups, and that can be explained by the practice of horse riding. They include:

- The entheseal changes at the ischial tuberosity and anterior inferior iliac spine of the coxal bone, the adductor tubercle, trochanteric fossa and linea aspera of the femur, the soleal line of the tibia and the calcaneal tuberosity, with the entheseal changes at the adductor tubercle and the calcaneal tuberosity being the most reliable ones.

- Poirier's facet on the femoral neck, which should be distinguished from other modifications of the femoral head-neck junction.

- Schmorl's nodes, especially at the thoracolumbar transition and including large nodes.

- A vertical ovalisation of the acetabulum.

Based on their nature, and considering the strict methodological criteria applied in this study and the pertinent selected samples, our results suggest that these skeletal changes can be used with confidence to evaluate, statistically, the possibility that a population of interest was practicing horse riding. For this purpose, one should compare the frequencies and values of these features with pertinent populations of known riders and non-riders. In this respect, future comparative analyses could use the data that we have recorded. Along with these skeletal changes, we also propose to consider the higher frequency of acute traumatic fractures of the upper limb - notably the clavicle, relatively to other bones' fractures as a complementary indicator.

Furthermore, comparisons between groups revealed no significant differences between both Hungarian groups, with and without riding deposit, for a majority of analyses. If only the individuals with riding deposits in their graves were practicing horse riding, we would have expected to observe more differences for all skeletal changes between them and the group of individuals without riding deposit. This led us to suggest that the individuals from the Hungarian cemetery without riding-related deposits in their graves were likely riding horses as well. This would explain why historical sources mention great numbers of riders in the populations from the Conquest period, while only a minority of the graves in the Carpathian basin contain riding deposits (Róna-Tas 1999, Engel 2001, Vörös 2013). This funerary practice could, as a consequence, carry a more social or symbolic significance (e.g., recognition of a certain status, rank or military skills).

\section{Research significance and perspectives}

We consider that we have achieved most of the two objectives of this research. It represents, indeed, a methodological contribution to the research on activity reconstructions in past populations, with the identification of skeletal changes that can probably be related to the practice of horse riding. For this purpose, we acknowledged the limitations of previous studies focusing on this topic and attempted to go further. In the end, we can claim that this study represents the first methodological contribution to the research on horse riding-related skeletal changes to meet all the following criteria:

- It relies on an anthropological collection of confirmed horse riders, with a direct association between particular individuals and the activity provided by archaeological evidence.

- It includes a comparison group from a population in which the practice of horse riding was very unlikely. 
- It is based on a systematic analysis of different types of skeletal changes commonly used as indicators of activity and behaviour in past populations.

- It relies on samples large enough to allow statistical analyses (unlike several studies based on single cases).

- It takes into account multiple methodological bias factors such as sex, age and pathological conditions, and attempts to limit their influence using strict analytical criteria.

- It discusses the observed skeletal changes and their possible relationship with the practice of horse riding in light of anatomical and functional aspects, with the support of sports medicine literature.

Specifically, we must highlight the pertinence of the archaeological collection that was used, and which represents an essential strength of this study. The series from the 10thcentury cemetery of Sárrétudvari-Hizóföld included, indeed, 32 graves with either a deposit of equipment related to horse riding, either horse bones, or both, in association with the individuals. The strict methodological criteria used in this investigation led us to include 17 of these individuals, which represents, to the best of our knowledge, the largest homogeneous anthropological sample investigated for horse riding-related skeletal changes for which archaeological evidence provides a direct link between each individual and this activity.

Furthermore, we also have achieved our second main objective, which was to bring an ethnoarchaeological contribution: the results of this study improved, indeed, our understanding of the societies from the Hungarian Conquest period and their funerary practices, in particular.

We took into consideration most of the pitfalls inherent to research on activity-related skeletal changes, leading to several limitations, such as relatively restricted sample sizes in the archaeological groups. This represents one of the main aspects that we should improve in the future by including additional collections from the Hungarian Conquest period, but also other nomadic and semi-nomadic populations (e.g., Early and Middle Avars, Mongols, Post-Contact Native Americans).

Besides, the multifactorial aetiology of the skeletal changes represented one of the main difficulties for their interpretation in terms of activity. This limitation notably concerned the entheseal changes, which can be related to mechanical factors, but also be influenced by age, sex, genetics or pathological conditions (Dutour 1992, Jurmain et al. 2012, Milella et al. 2012, Schrader 2019). In that regard, we performed the exploratory analysis of the microarchitecture of a well-defined and documented enthesis, the bicipital tuberosity of the radius. Using micro-CT acquisitions and $3 \mathrm{D}$ reconstructions of the canals of the cortical bone (Coqueugniot et al. 2010, Coqueugniot et al. 2011, Djukic et al. 2015), we observed that some microstructural variations could allow, with further research, distinguishing entheseal changes related to activity from those related to other factors, thus contributing to improving the reconstruction of activities of past populations.

In the end, a notable conclusion that can be drawn is how essential it is to apply strict methodological criteria to avoid the major pitfalls associated with this type of research. Besides, we emphasize the fundamental importance of selecting pertinent anthropological collections, where specific activities can be assumed from direct evidence, as well as comparison groups of non-performers. These are determinant factors for the reliable identification of activity-related skeletal changes among past populations. 


\section{References}

Alves Cardoso, F., Henderson, C.Y. (2013): The categorisation of occupation in identified skeletal collections: International Journal of Osteoarchaeology, 23: 186-196. DOI: 10.1002/oa.2285

Anđelinovic, Š., Anteric, I., Škoric, E., Basic, Ž. (2015): Skeleton changes induced by horse riding on medieval skeletal remains from Croatia. International Journal of the History of Sport, 32: 708-721. DOI: $10.1080 / 09523367.2015 .1038251$

Anthony, D.W. (2007): The Horse, the Wheel, and Language: How Bronze-Age Riders from the Eurasian Steppes Shaped the Modern World. Princeton University Press, Princeton, NJ.

Baillif-Ducros, C. (2018): La pratique de la monte à cheval au haut Moyen Âge (fin Ve-VIIe siecle) dans le nord-est de la Gaule. État des connaissances archéologiques, recherche méthodologique sur le "syndrome du cavalier" et application d'un nouveau protocole d'etude aux populations mérovingiennes. Doctoral dissertation. Université de Caen Normandie, Caen, France.

Baillif-Ducros, C., Truc, M.-C., Paresys, C., Villotte, S. (2012): Approche méthodologique pour distinguer un ensemble lésionnel fiable de la pratique cavalière. Exemple du squelette de la tombe 11 du site de "La Tuilerie" a Saint-Dizier (Haute-Marne): VIe siecle. Bulletins et Mémoires de la Société d'Anthropologie de Paris, 24: 25-36. DOI: 10.1007/s13219-011-0049-8

Belcastro, M.G., Facchini, F. (2001): Anthropological and cultural features of a skeletal sample of horsemen from the medieval necropolis of Vicenne-Campochiaro (Molise, Italy). Collegium Antropologicum, 25: 387-401.

Blondiaux, J. (1994): À propos de la dame d'Hochfelden et de la pratique cavalière: discussion autour des sites fonctionnels fémoraux. In: Buchet, L. (Ed.) Actes des 6e Journées Anthropologiques. Dossier de Documentation Archéologique n 17. CNRS Éditions, Paris, France. pp. 97-109.

Bridges, P.S. (1989): Spondylolysis and its relationship to degenerative joint disease in the prehistoric Southeastern United States. American Journal of Physical Anthropology, 79: 321-329. DOI: 10.1002/ajpa.1330790308

Buikstra, J.E., Ubelaker, D. H. (Eds, 1994): Standards for data collection from human skeletal remains. Proceedings of a seminar at the Field Museum of Natural History. Arkansas Archaeological Survey, Fayetteville, AR, USA.

Buzon, M.R., Richman, R. (2007): Traumatic injuries and imperialism: The effects of Egyptian colonial strategies at Tombos in upper Nubia. American Journal of Physical Anthropology, 133: 783-791. DOI: 10.1002/ajpa.20585

Capasso, L., Kennedy, K.A.R., Wilczak, C.A. (1999): Atlas of Occupational Markers on Human Remains. Edigrafital, Teramo, Italy.

Cardoso, H.F.V. (2006): Brief communication: The collection of identified human skeletons housed at the Bocage Museum (National Museum of Natural History), Lisbon, Portugal. American Journal of Physical Anthropology, 129: 173-176. DOI: 10.1002/ajpa.20228

Coqueugniot, H., Desbarats, P., Dutailly, B., Dutour, O. (2011): Procédé de modélisation d'une pièce formée de tissu osseux. Patent $\mathrm{n}^{\circ} \mathrm{BR} 39066$, France.

Coqueugniot, H., Desbarats, P., Dutailly, B., Panuel, M., Dutour, O. (2010): Les outils de l'imagerie médicale et de la 3D au service des maladies du passe. In: Vergnieux, R., Delevoie, C. (Eds) Actes du colloque Virtual Retrospect 2009. Ausonius Editions, Collection Archéovision, Pessac, France. pp. 177-180.

Courtaud, P., Rajev, D. (1998): Osteomorphological features of nomadic riders: Some examples from Iron Age populations located in southwestern Siberia. In: Pearce, M., Tosi, M. (Eds) Papers from the EAA Third Annual Meeting at Ravenna, 1997. BAR International Series 717(1), Pre- and protohistory. Archaeopress, Oxford, UK. pp. 110-113.

Djukic, K., Miladinovic-Radmilovic, N., Draskovic, M., Djuric, M. (2018): Morphological appearance of muscle attachment sites on lower limbs: Horse riders versus agricultural population. International Journal of Osteoarchaeology, 28: 656-668. DOI: 10.1002/oa.2680

Djukic, K., Milovanovic, P., Hahn, M., Busse, B., Amling, M., Djuric, M. (2015): Bone microarchitecture at muscle attachment sites: The relationship between macroscopic scores of entheses and their cortical and trabecular microstructural design. American Journal of Physical Anthropology, 157: 81-93. DOI: 10.1002/ajpa.22691 
Dutour, O. (1986): Enthesopathies (lesions of muscular insertions) as indicators of the activities of Neolithic Saharan populations. American Journal of Physical Anthropology, 71: 221-224. DOI: 10.1002/ajpa.1330710209

Dutour, O. (1992): Activites physiques et squelette humain: le difficile passage de l'actuel au fossile. Bulletins et Memoires de la Societe d'Anthropologie de Paris, 4: 233-241. DOI: 10.3406/bmsap.1992.2319

Engel, P. (2001): The Realm of St Stephen. A History of Medieval Hungary. I.B. Tauris Publishers, London, UK, New York, USA. pp. 895-1526.

Erickson, J.D., Lee, D.V., Bertram, J.E.A. (2000): Fourier analysis of acetabular shape in Native American Arikara populations before and after acquisition of horses. American Journal of Physical Anthropology, 113: 473-480. DOI: 10.1002/1096-8644(200012)113:4<473::AIDAJPA3>3.0.CO;2-5

Finnegan, M. (1978): Non-metric variation of the infracranial skeleton. Journal of Anatomy, 125: 23-37.

Fuka, M.R. (2018): Activity markers and horse riding in Mongolia: Entheseal changes among Bronze and Iron Age human skeletal remains. Master thesis. Purdue University, West Lafayette, IN.

Hawkey, D.E., Merbs, C.F. (1995): Activity-induced musculoskeletal stress markers (MSM) and subsistence strategy changes among ancient Hudson Bay Eskimos. International Journal of Osteoarchaeology, 5: 324-338. DOI: 10.1002/oa.1390050403

Henderson, C.Y., Mariotti, V., Pany-Kucera, D., Villotte, S., Wilczak, C.A. (2016): The New 'Coimbra Method': A Biologically Appropriate Method for Recording Specific Features of Fibrocartilaginous Entheseal Changes. International Journal of Osteoarchaeology, 26: 925-932. DOI: $10.1002 / \mathrm{oa} .2477$

Jurmain, R.D. (1999): Stories from the Skeleton. Behavioral Reconstruction in Human Osteology. Gordon and Breach, Amsterdam, the Netherlands.

Jurmain, R.D., Alves Cardoso, F., Henderson, C.Y., Villotte, S. (2012): Bioarchaeology's Holy Grail: The Reconstruction of Activity. In A.L. Grauer (Ed.) A Companion to Paleopathology. WileyBlackwell, Chichester, UK. pp. 531-552.

Khudaverdyan, A., Khachatryan, H., Eganyan, L. (2016): Multiple trauma in a horse rider from the Late Iron Age cemetery at Shirakavan, Armenia. Bioarchaeology of the Near East, 10: 47-68.

Knüsel, C.J., Göggel, S., Lucy, D. (1997): Comparative degenerative joint disease of the vertebral column in the medieval monastic cemetery of the Gilbertine Priory of St. Andrew, Fishergate, York, England. American Journal of Physical Anthropology, 103: 481-495. DOI: 10.1002/(sici)1096-8644(199708)103:4<481::aid-ajpa6>3.0.co;2-q

Larsen, C.S. (1997): Bioarchaeology: Interpreting behaviour from the human skeleton. Cambridge University Press, Cambridge, UK.

Mariotti, V., Facchini, F., Belcastro, M.G. (2004): Enthesopathies - proposal of a standardized scoring method and applications. Collegium Antropologicum, 28: 145-159.

Mariotti, V., Facchini, F., Belcastro, M.G. (2007): The study of entheses: proposal of a standardised scoring method for twenty-three entheses of the postcranial skeleton. Collegium Antropologicum, 31: 291-313.

Merbs, C.F. (1989): Spondylolysis: its nature and anthropological significance. International Journal of Anthropology, 4: 163-169. DOI: 10.1007/bf02446238

Milella, M., Belcastro, M.G., Zollikofer, C.P.E., Mariotti, V. (2012): The effect of age, sex, and physical activity on entheseal morphology in a contemporary Italian skeletal collection. American Journal of Physical Anthropology, 148: 379-388. DOI: 10.1002/ajpa.22060

Miller, E., Reinhard, K.J. (1991): The Effect of Horseback Riding on the Omaha and Ponca: Paleopathological Indications of European Contact. Paper presented at the Plains Anthropology Conference, Lawrence, KS, 13-16 November 1991.

Molleson, T., Hodgson, D. (1993): A cart driver from Ur. Archaeozoologia, VI: 93-106.

Molnar, P. (2006): Tracing prehistoric activities: Musculoskeletal stress marker analysis of a stoneage population on the Island of Gotland in the Baltic sea. American Journal of Physical Anthropology, 129: 12-23. DOI: 10.1002/ajpa.20234 
Nepper, I.M. (2002): Hajdú-Bihar megye 10-11. századi sírleletei I-II. (Magyarország honfoglalás és kora Árpád-kori sírleletei 3). Déri Múzeum - Magyar Nemzeti Múzeum - MTA Régészeti Intézete, Budapest - Debrecen, Hungary.

Pálfi, Gy. (1992): Traces des activités sur les squelettes des anciens Hongrois. Bulletins et Memoires de la Societe d'Anthropologie de Paris, 4: 209-231. DOI: 10.3406/bmsap.1992.2318

Pálfi, Gy. (1997): Maladies dans l'Antiquite et au Moyen-Âge. Paleopathologie comparee des anciens Gallo-Romains et Hongrois. Bulletins et Memoires de la Societe d'Anthropologie de Paris, 9: 1-205. DOI: 10.3406/bmsap.1997.2472

Radi, N., Mariotti, V., Riga, A., Zampetti, S., Villa, C., Belcastro, M.G. (2013): Variation of the anterior aspect of the femoral head-neck junction in a modern human identified skeletal collection. American Journal of Physical Anthropology, 152: 261-272. DOI: 10.1002/ajpa.22354

Révész, L. (2003): The cemeteries of the Conquest period. In: Visy, Z. (Ed.) Hungarian Archaeology at the Turn of the Millennium. Ministry of National Cultural Heritage, Teleki László Foundation, Budapest, Hungary. pp. 338-343.

Rogers, J., Waldron, T. (1995): A field guide to joint disease in archaeology. John Wiley \& Sons, Chichester, UK.

Róna-Tas, A. (1999): Hungarians and Europe in the early Middle Ages: An introduction to early Hungarian history. Central European University Press, Budapest, Hungary.

Sarry, F., Courtaud, P., Cabezuelo, U. (2016) La sepulture multiple latenienne du site de Gondole (Le Cendre, Puy-de-Dome). Bulletins et Memoires de la Societe d'Anthropologie de Paris, 28 : 72-83. DOI: $10.1007 / \mathrm{s} 13219-016-0151-\mathrm{z}$

Schrader, S. (2019): Activity, Diet and Social Practice. Addressing Everyday Life in Human Skeletal Remains. Springer International Publishing, Cham, Switzerland.

Tichnell, T.A. (2012): Invisible Horsewomen: Horse Riding and Social Dynamics on the Steppe. Doctoral dissertation. Michigan State University, East Lansing, MI.

Ustundag, H. (2009): Schmorl's nodes in a post-medieval skeletal sample from Klostermarienberg, Austria. International Journal of Osteoarchaeology, 19: 695-710. DOI: 10.1002/oa.993

Ustundag, H., Deveci, A. (2011): A possible case of Scheuermann's disease from Akarcay Hoyuk, Birecik (Sanluurfa, Turkey). International Journal of Osteoarchaeology, 21: 187-196. DOI: 10.1002/oa.1120

Villotte, S. (2006): Connaissances medicales actuelles, cotation des enthesopathies: nouvelle methode. Bulletins et Memoires de la Societe d'Anthropologie de Paris, 18: 65-85.

Villotte, S., Knüsel, C.J. (2009): Some remarks about femoroacetabular impingement and osseous non-metric variations of the proximal femur. Bulletins et Memoires de la Societe d'Anthropologie de Paris, 21: 95-98.

Vörös, I. (2013): Adatok a honfoglalás kori lovastemetkezésekhez. In: Révész, L., Wolf, M. (Eds) A honfoglalás kor kutatásának legújabb eredményei. Tanulmányok Kovács László 70. születésnapjára. Szegedi Tudományegyetem Régészeti Tanszék, Szeged, Hungary. pp. 321-336.

Weiss, E., Jurmain, R.D. (2007): Osteoarthritis revisited: A contemporary review of aetiology. International Journal of Osteoarchaeology, 17: 437-450. DOI: 10.1002/oa.889

\section{Articles published in peer-reviewed journals in the topic of the dissertation}

Berthon, W., Rittemard, C., Tihanyi, B., Pálfi, Gy., Coqueugniot, H., Dutour, O. (2015): Threedimensional microarchitecture of entheseal changes: preliminary study of human radial tuberosity. Acta Biologica Szegediensis, 59(1): 79-90.

Berthon, W., Tihanyi, B., Kis, L., Révész, L., Coqueugniot, H., Dutour, O., Pálfi, Gy. (2019): Horse riding and the shape of the acetabulum: Insights from the bioarchaeological analysis of early Hungarian mounted archers (10th century). International Journal of Osteoarchaeology, 29(1): 117-126. DOI: $\underline{10.1002 / 0 a .2723}$ 
Tihanyi, B., Bereczki, Zs., Molnár, E., Berthon, W., Révész, L., Dutour, O., Pálfi, Gy. (2015): Investigation of Hungarian Conquest Period (10th century AD) archery on the basis of activityinduced stress markers on the skeleton. Acta Biologica Szegediensis, 59(1): 65-77.

Tihanyi, B., Berthon, W., Kis, L., Váradi, O., Dutour, O., Révész, L., Pálfi, Gy. (2020): "Brothers in arms": Activity-related skeletal changes observed on the humerus of individuals buried with and without weapons from the 10th-century CE Carpathian Basin. International Journal of Osteoarchaeology, early view. DOI: 10.1002/oa.2910

Tihanyi, B., Révész, L., Berthon, W., Dutour, O., Molnár, E., Pálfi, Gy. (2015): Aktivitás okozta csontelváltozások: a honfoglalás kori íjászsírok problémakörének újabb megközelítése. Anthropologiai Közlemények, 56: 105-127. DOI: 10.20330/AnthropKozl.2015.56.105

\section{Other important publications of the Author}

Berthon, W., Tihanyi, B., Pálfi, Gy., Dutour, O., Coqueugniot, H. (2016): Can micro-CT and 3D imaging allow differentiating the main aetiologies of entheseal changes? In: Gál, S. (Ed.) The Talking Dead. New results of the Central and Eastern European Osteoarchaeology. Proceedings of the First Conference of the Török Aurél Anthropological Association from Târgu-Mureş: 1315 November 2015. MEGA Publishing House, Cluj-Napoca, Romania. pp. 29-41.

Berthon, W., Tihanyi, B., Révész, L., Dutour, O., Coqueugniot, H., Pálfi, Gy. (2018): The identification of horse riding through the analysis of entheseal changes: Methodological considerations. In: Gál, S. (Ed.) The Talking Dead 2. Past and Present of Biological Anthropology. The Heritage of Török Aurél`s Oeuvre. New results from ancient tuberculosis and leprosy research. Proceedings of the Second International Conference of the TAAA from TârguMureş, 13-15 October 2017. MEGA Publishing House, Cluj-Napoca, Romania. pp. 15-28.

Berthon, W., Thomas, A., Thomann, A., Rottier, S. (2015): Faut-il mener une diagnose sexuelle in situ dans les grands ensembles funéraires? Le cas du cimetière médiéval de Val-de-Reuil "Le Chemin aux Errants" (Eure). Bulletins et Mémoires de la Société d'Anthropologie de Paris, 27(12): 26-41. DOI: $10.1007 / \mathrm{s} 13219-015-0121-\mathrm{x}$

Spekker, O., Hunt, D.R., Váradi, O., Berthon, W., Molnár, E., Pálfi, Gy. (2018): Rare manifestations of spinal tuberculosis in the Robert J. Terry Anatomical Skeletal Collection (National Museum of Natural History, Smithsonian Institution, Washington, DC, USA). International Journal of Osteoarchaeology 28(3): 343-353. DOI: 10.1002/oa.2658

Tihanyi, B., Spekker, O., Berthon, W., Kis, L., Bereczki, Zs., Molnár, E., Dutour, O., Révész, L., Pálfi, Gy. (2018): Sports medicine and sports traumatology aspects of archery. Anatomical data for the better understanding of the archery-related skeletal changes. In: Gál, S. (Ed.) The Talking Dead 2. Past and Present of Biological Anthropology. The Heritage of Török Aurél`s OEuvre. New results from ancient tuberculosis and leprosy research. Proceedings of the Second International Conference of the Török Aurél Anthropological Association from Târgu-Mureş: 13-15 October 2017. MEGA Publishing House, Cluj-Napoca, Romania. pp. 123-136.

van den Bossche, B., Corona, A., Berthon, W. (2017): La nécropole de l'âge du Bronze du Cornouiller. État des recherches et résultats préliminaires. Actes de la journée archéologique d'Ile-de-France 2015 (16 01 2016, Cergy). DRAC Ile-de-France/SRA, Paris, France. pp. 71-78.

Mailing address: William Berthon

Department of Biological Anthropology

University of Szeged

Közép fasor 52.

6726 Szeged

Hungary

william.berthon@gmail.com 